\title{
Development of Local Wisdom-Based Learning Media with Prezi Applications in Social Arithmetic
}

\author{
Choirudin 1 , M. Saidun Anwar ${ }^{2}$, Anindya Eka Juwarlan ${ }^{3}$, Dhita Paranita Ningtyas ${ }^{4}$, Sigit Dwi Laksmana ${ }^{5}$ \\ 1, 2, 3 Institut Agama Islam Ma'airf NU (IAIMNU) Metro Lampung, Indoneia \\ ${ }^{4}$ Universitas Trilogi Jakarta, Indonesia \\ ${ }^{5}$ Universitas Muhammadiyah Ponorogo, Jawa Timur, Indonesia \\ Correspondence: $\mathbb{M}$ choirudiniaimnumetro@gmail.com
}

\author{
Article Info \\ Article History \\ Received : 01-01-2021 \\ Revised : 15-02-2021 \\ Accepted : 15-02-2021

\section{Keywords: \\ Learning Media; \\ Local Wisdom; \\ Prezi Applications; \\ Social Arithmetic.}

\begin{abstract}
The aim study to create and develop local wisdom-based learning media with Prezi applications in Social Arithmetic Materials. This type of research is Research and Development (RND), using development steps according to Borg \& Gall which has been transformed by Sugiyono. The development steps are limited to six steps. Among them; 1) Results of Need Analysis; 2) Problem Identification and Data Collection; 3) Product Design Results; 4) Design Product Validation; 5) Design Revision Results (Initial Product); 6) Small Group Trial; and 7) Field Trials (Large Group Trial). Local wisdom-based learning media have been developed with the application of Prezi on social arithmetic material by collecting data on local wisdom on the livelihood of Buminabung residents by taking documentation in the form of photos and information related to the local wisdom put them on the slide Prezi. The development of local wisdom-based learning media with the application of Prezi on social arithmetic material is feasible to use in learning. The assessment of material experts and media experts with an assessment of $80 \%$ in the feasible category and $91 \%$ in the very feasible category. The results of the trials carried out were small group trials in class VII A with a feasibility percentage of $76 \%$ in the feasible category. In the field trials conducted by class VII A MTs Ma'arif 05 Buminabung, the percentage was $79 \%$ in the feasible category.
\end{abstract}

\section{Introduction}

Media is widely understood, it is the human, material, or events that establish the conditions which enable students to acquire the knowledge, skills, or attitudes (Kamelia, 2019; Sari \& Setiawan, 2018). In this case, the teacher, textbook, and school environment are the media. (2014b) revealed that the use of learning media in the learning process can generate new desires and interests, motivation, and stimulation of learning activities, and even have psychological effects on students. The practical benefit of using learning media in the teaching and learning process is to clarify the presentation of messages and information to facilitate and improve learning processes and results, can increase and direct attention to children that can lead to motivation to learn, can overcome sensory limitations, space and time (2014a, 2020).

Each subject matter certainly has different levels of difficulty. On the one hand, there is a subject matter that does not require assistive devices, but on the other hand, there is a material that requires media props, such as a globe, graphics, images, and so on. Study materials with high levels of difficulty are of course difficult for students to process. Especially for students who do not like the learning material delivered. Students feel bored and tired quickly of course can not be avoided, because the teacher's explanation is difficult to understand (Baten, Pixner, \& Desoete, 2019; 2019). Wise teachers are certainly 
aware that students' boredom and fatigue are derived from explanations given by teachers that are confusing and have no focus on problems. This of course needs to be addressed.

Media learning to use is still limited. This causes the attitude of students who are less enthusiastic when learning, low response feedback from students for questions and explanations from the teacher, lack of attention and concentration of students, and the lack of media that support the learning process of mathematics, teachers still use cartons and styrofoam. Therefore, an interactive learning media is needed that can improve student focus (Anwar, Choirudin, Ningsih, Dewi, \& Maseleno, 2019; 2018).

Media are various components of the learning environment that are used to help students to learn. Learning media can be understood as a means to deliver or distribute subject matter in a planned manner to create a conducive, effective, and efficient learning environment (Al-Hammouri, 2018; Ariffin, Samsudin, Zain, Hamzah, \& Ismail, 2017; Chamidy, Degeng, \& Ulfa, 2020; Setiawan \& Wawan, 2020).

The existence of media is not the only component that guarantees the success of the learning process, but without media that supports learning activities cannot be maximally implemented. Media plays an important role in improving the quality of education, including improving the quality of mathematics education. Learning media can be used to build understanding and mastery of educational objects. By using media, abstract concepts and mathematical symbols become more concrete (Anderton, 2019; Daniels, 1982; et al., 2019).

As a tool, the media has the function of opening the way to achieving teaching goals. This is based on the belief that learning with media helps to improve student learning activities for a long period (Byrne, 2016; Marini et al., 2020). That means student learning activities with the help of media will produce better learning processes and results than without media assistance.

Prezi is a presentation software as a means to explore various ideas on a virtual canvas, this software has excellent features that use the Zooming User Interface (ZUI), which allows users to enlarge and reduce the presentation media (Wati, Hartini, Novita, \& Mahtari, 2017). The advantages of software Prezi is that he can also integrate objects such as text, images, videos, and other media presentations placed in media presentations, making it easier for audiences to understand the contents of the presentation material (AlHammouri, 2018; Aruan, Sari, \& Bengar Harahap, 2020; 2016).

Prezi is a medium that can help teachers to convey complex messages and become more attractive in dynamic ways (Hartini, Misbah, Dewantara, Oktovian, \& Aisyah, 2017). So that students can be motivated in the learning process. This media is accompanied by a more varied theme, Prezi also has more active advantages compared to many where the students listen to the learning process less effectively to visualize the material presented (Al-Hammouri, 2018).

Applying the values of local wisdom such as raising the diversity of local cultures can make the younger generation have responsibility for the environment. One effort to apply the values of local wisdom in teaching mathematics in schools is through the development of local knowledge-based learning media around. These efforts are needed to improve students' understanding of mathematics in the learning process through knowledge resources around them (Haylock \& Cockburn, 2017; Ningsih, Anwar, Choirunnisa, \& Maseleno, 2020; et al., 2019). 
The learning of mathematics is done by utilizing the knowledge resources around, it will be easier to understand the material presented. Because, the application of the knowledge they get from schools can be seen real for the interests and benefits of the surrounding environment (2019). Based on previous research on the development of media through multimedia Prezi desktop has a high level of effectiveness and attractiveness (Ali, Saher, \& Najwan, 2020; Nur Kumala, Agus Setiawan, Amin, Gipayana, \& Atul Karvilla, 2019). Other research on the development of (Firdaus, Samsuri, \& Susantini, 2019) can be concluded that research and product development in the form of textbooks based on local wisdom are based on the results of material experts and media experts as well as product testing on systematic aspects, content suitability, material development, cognitive development, the use of language, illustrations of harmony, morals, and idioms of standard regionalism can increase student motivation. So Prezi and local wisdom can be used as an effort to increase student learning motivation.

\section{Method}

This study uses Research and Development which is used to make products, and test the effectiveness of products (2017). In simple terms, Research and Development aim to find, improve, develop, produce products, test products, and produce a standardized product according to the indicators set. This study develops local wisdom-based learning media with the application of Prezi on social arithmetic material. In this study, researchers used the Borg and Gall model (Gall, Gall, \& Borg, 2014). Research and development were carried out at MTs Ma'arif 05 Buminabung and carried out in class VII. Respondents in this study were VII grade students who had not received Social Arithmetic material.

\section{Result and Discussion \\ Result}

\section{Results of Need Analysis}

From the results of a needs analysis conducted by direct observation to school and to implement interviews of teachers found that the use of instructional media is still limited, the researchers obtain the main results of the research while yes needed development of instructional media based on local wisdom with the application Prezi on material Social Arithmetic. Research and development were carried out at MTs Ma'arif 05 Buminabung and carried out in class VII. Respondents in this study were VII grade students who had not received Social Arithmetic material. In this study, researchers used a research and development model by adapting Borg and Gall which was modified by (2017) from stage one to seven-stage.

In research and development carried out produce learning media based on local wisdom with the Prezi application on Social Arithmetic material. The results of the needs analysis carried out are as follows:

\section{Results of the Stages of Problem Identification and Data Collection}

The results at the problem identification stage and data collection from the literature review and preresearch were carried out at the time of the needs analysis.

On the theoretical basis found theories that support the feasibility and function of Prezi media as learning media. Based on the literature review, Prezi can shift the learning paradigm that was originally teacher-centered to be student-centered and the teacher is only a facilitator so students become active in learning, no longer rely on the teacher as a single source. The advantages of Prezi can accommodate the 
diversity of learning styles because Prezi is programmed to be able to display visual, audio, and animated media. Prezi application program is also a unique medium because in it there are forms of presentation that are very different from the general presentation.

Pre-research or field observation is conducted to determine the needs of teachers and students regarding Prezi learning media. Field observations were carried out by conducting interviews with teachers, principals, and students. The criteria for observation questions are about the skills possessed by educators in using and developing learning media, the curriculum used and the approach used in school, and responses of students in using Prezi learning media.

The results of the pre-research or field observations obtained were, the need for the use of Prezi learning media in Mathematics learning in class, and the need to develop Prezi learning media as learning media.

\section{Product Design Results}

Based on the data from pre-research or field observations, the product specifications to be developed are local wisdom-based learning media with applications Prezi which can help educators and students in the learning process. The following is a plan for developing Prezi learning media using a realistic approach as a learning media for Mathematics developed.

Arrange media according to core competencies, basic competencies, indicators, and learning objectives.

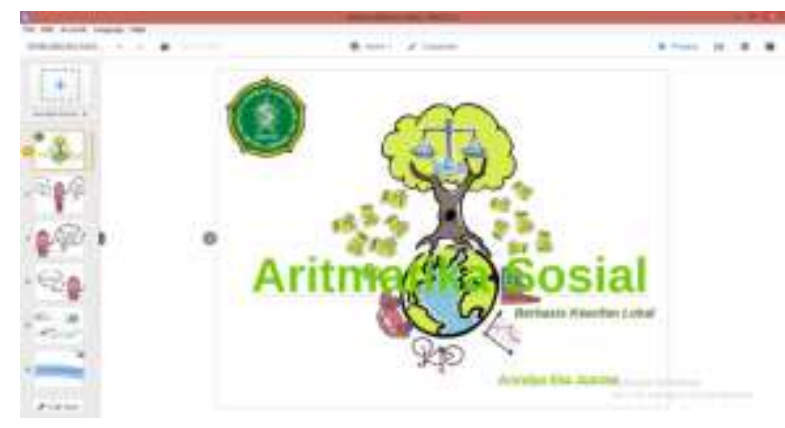

Figure 1. Cover Learning Media

Design template of local wisdom based learning media on Prezi application for Social Arithmetic material.

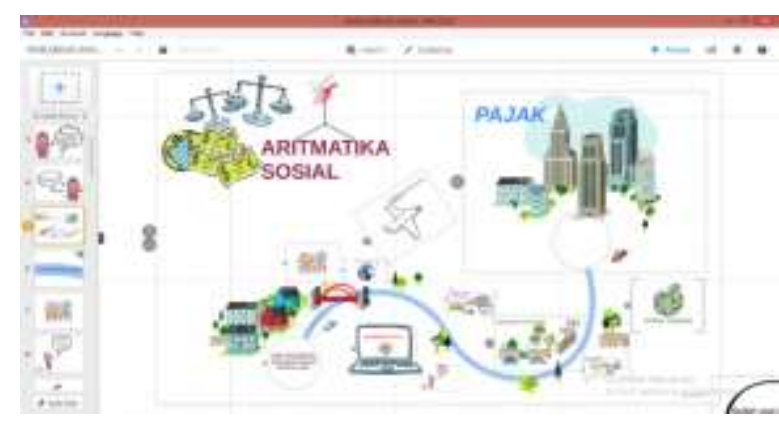

Figure 2. Learning Media Template Design

Arrange the media by linking local wisdom to Social Arithmetic material 


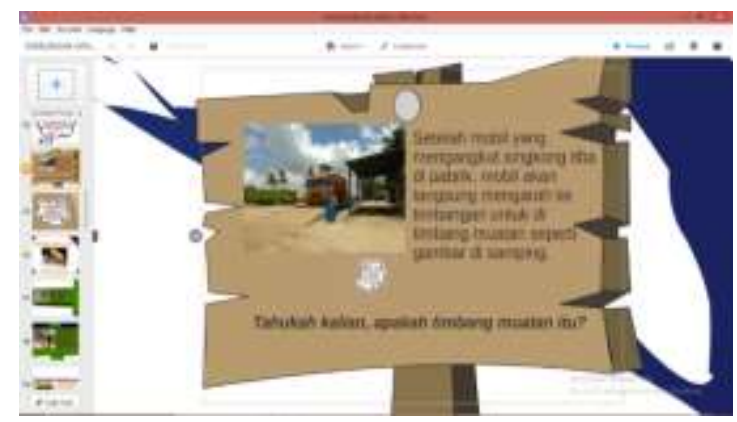

Figure 3. Local Wisdom-Based Social Arithmetic

In the preparation of learning, media researchers link the local wisdom of the Buminabung area into the material contained in the media. Buminabung is one of the Districts in Central Lampung Regency, located side by side with Rumbia District. The local wisdom of Buminabung used is the place and typical livelihood activities of Buminabung residents, the discussion is as follows:

Although the name is Florindo Makmur Rumbia factory, this factory is located in Buminabung, precisely East Buminabung. The name of the factory which still uses the name Rumbia is because Buminabung was part of Rumbia District, then Rumbia District was broken so Buminabung was separated from Rumbia Sub-District and became Buminabung Sub-District area. Buminabung residents often refer to this as the BW Cassava Factory.

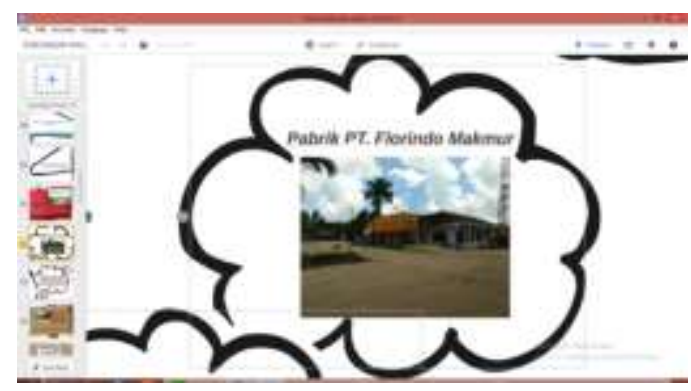

Figure 4. Florindo Makmur Rumbia Factory on the Prezi Display

The activity of buying and selling cassava at Factory is a local wisdom material that is used in the learning media subchapter of the selling price and purchase price. The process of buying and selling cassava from Buminabung residents at Florindo Makmur Rumbia Factory. After the transport vehicle arrives at the factory, the car will be directly driven to the weighing device to be weighed (gross).

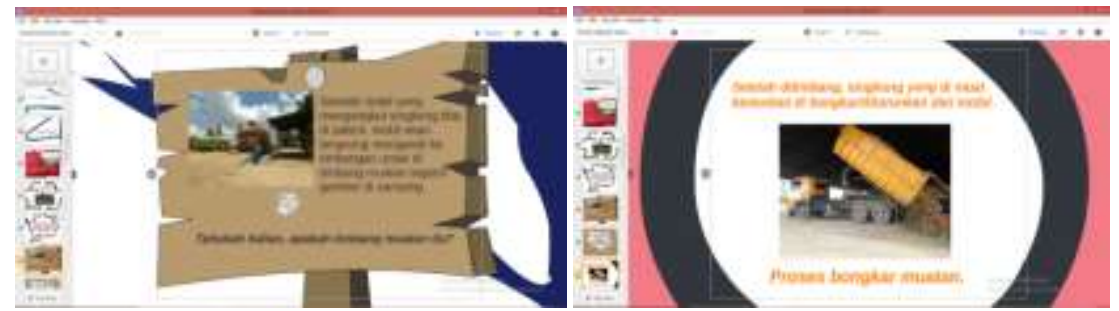

Figure 5. Weigh Load and Unload at Prezi Display

After weighing, the cassava is then lowered from the car, or in Buminabung it is said to be dismantled.

Bakmi is the food most often found in Buminabung. This food is very popular in Buminabung. The process of making and selling Buminabung bakmi is a local wisdom ingredient that is used in the media sub- 
chapter of profit and percentage. The process of making bakmi in Buminabung precisely Buminabung Ilir is as follows:

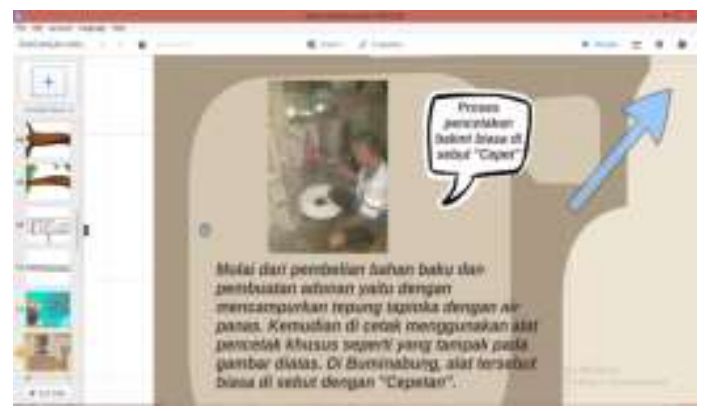

Figure 6. Bakmi Printing Process

Then the noodles are dipped into cold water with the aim that noodles do not clot.

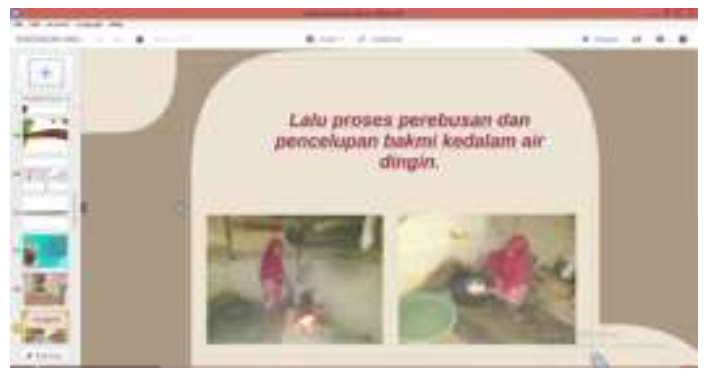

Figure 7. Bakmi's Boiling and Dyeing Process in Cold Water

\section{Design Product Validation}

After the product has been successfully developed, the next step is to test the feasibility of the model using product validation. Validation of the design or product is done after making the initial product. Validation is done in two kinds, namely material expert validation and media expert validation. The validation sheet is given by material experts and media experts as validators.

Validation of media experts is the same as material experts which are done by filling out questionnaires consisting of two aspects, including the display and programming aspects with six components, layout design, text/typography, image, animation, packaging, and usage. With a total of 14 statements.

The assessment by the material validation of the above material can be seen in the learning aspects of getting a percentage of eligibility of $80 \%$. Material expert validation was done by filling out the assessment questionnaire sheet. There are several aspects of assessment contained in the assessment validation sheet. In each aspect, there are several statements. From 2 aspects there are fourteen statements filled by material experts. the assessment by the material validation of the above material can be seen in the display aspect getting a percentage of eligibility of $90 \%$.

\section{Design Revision Results (Initial Product)}

After the product validation has been done by the material expert validator and media expert, a suggestion is obtained from the validator. Then the advice given is used as input to revise the initial product design. The results of the design revisions can be explained as follows: The results of the revision of material 
experts in the form of improvements from suggestions for learning media based on local wisdom with the application Prezi on Social Arithmetic material according to the validator.

Material expert validator for local wisdom-based learning media with the Prezi application on social artistic material. The results of the revision of media experts in the form of improvements from suggestions for local wisdom-based learning media with applications Prezi on Social Arithmetic material according to the validator. Media expert validator on local wisdom-based learning media with the Prezi application on social artistic material.

Test local wisdom based learning media with the Prezi application this revised arithmetic material was carried out in one school. Trials include small group trials and field trials. The trial was carried out during the learning process, after learning with local wisdom-based learning media with the Prezi application in this Social Arithmetic material students are asked to fill out a questionnaire response.

\section{Small-Group Trial}

In the trial of small groups of local wisdom-based learning media products with the Prezi application on Social Arithmetic material as many as 10 people, students were given a questionnaire assessment of local wisdom-based learning media with the Prezi application on Social Arithmetic material, and students were asked to fill out the validation questionnaire provided. The total percentage of all aspects feasibility is $76 \%$

\section{Field Trials (Large Group Trial)}

Field trials were carried out at MTs Ma'arif 05 Buminabung. The purpose of the trial is to get an overview of students' responses to local wisdom-based learning media with the Prezi application for grade VII junior high school students on Social Arithmetic material. The initial step taken by the researcher was to show local wisdom-based learning media with the Prezi application in Social Arithmetic materials with the help of LCD projectors, the researcher explained the material about arithmetic to students. The last activity is to provide questionnaires for evaluating students' responses to the media. the total amount of all aspects per aspect is $79 \%$ and the total number of eligibility percentages.

\section{Discussion}

Prezi is software for internet-based presentations (SaaS). In addition to Prezi presentations can also be used as a tool to explore and share ideas on a virtual canvas. Prezi is superior because this program uses en: Zooming User Interface (ZUI), which allows the use of Prezi to zoom in and the media zooms out to display presentations.

Prezi is used as a tool to make presentations in a linear and non-linear form, namely structured presentations as examples of linear presentation or presentation in the form of mind maps as examples of non-linear presentations. In Prezi, presentations of text, images, videos, and other presentation media are placed on the canvas and can be grouped in the frames provided. The user then determines the relative size and position of all presentation objects and can circle and highlight those objects. To make a linear presentation, users can build the navigation path specified in the presentation. 
Prezi was originally developed by Hungarian architect Adam Somlai-Fischer as a virtualization architecture. The mission stated by Prezi is to "make ideas more interesting", and Prezi was deliberately created to be a tool for developing and sharing ideas in the form of visual narratives (2016).

Difference between Prezi and PowerPoint as explained earlier, that Prezi is software that helps internet-based presentations that are superior because this program has used en: Zooming User Interface (ZUI), which allows users to enlarge and minimize Prezi presentations. While Microsoft PowerPoint is one of the Microsoft Office application programs that are useful for making presentations in the form of slides. Usually, this application is used for presentations and teaching, it can be said that almost all students, students, office people, and others use this software (2016).

\section{Tabel 1. Difference between Prezi and PowerPoint}

\begin{tabular}{|c|c|c|}
\hline No. & Prezi & PowerPoint \\
\hline 1. & $\begin{array}{l}\text { To use Prezi, we as users must have an account } \\
\text { Prezi first. }\end{array}$ & $\begin{array}{l}\text { To use PowerPoint, we as users do not have } \\
\text { to have an account first. }\end{array}$ \\
\hline 2. & $\begin{array}{l}\text { Prezi is used and made online (using the } \\
\text { Internet) and can also be online }\end{array}$ & PowerPoint is used online. \\
\hline 3. & $\begin{array}{l}\text { Prezi has a variety of licensed themes that are } \\
\text { more varied. }\end{array}$ & PowerPoint only has a simple theme. \\
\hline 4. & $\begin{array}{l}\text { Used in slide form too, but on a virtual canvas. } \\
\text { This program is equipped with en: ZUI, which }\end{array}$ & There are no restrictions on usage. \\
\hline 5. & $\begin{array}{l}\text { allows users to zoom in and out of the } \\
\text { presentation screen. }\end{array}$ & More animated slides than Prezi \\
\hline 6. & $\begin{array}{l}\text { To use Prezi in the long run you have to pay, } \\
\text { while the public version is limited to } 30 \text { days. }\end{array}$ & The plant process can be online or offline. \\
\hline 7. & Prezi is easier to use & The editing process is fast because it's online. \\
\hline 8. & The installation process must be online & Directly saved on computer or laptop. \\
\hline 9. & $\begin{array}{l}\text { The editing process is long, depending on the } \\
\text { power of the Internet (online). }\end{array}$ & \\
\hline 10. & Edited data is stored on the web & \\
\hline
\end{tabular}

I want to use Prezi, you must have an account first, this account is created through an online website, how to use Prezi is as follows:

a. To create a Prezi account first open the browser application which is owned and then go to the web page www. Prezi.com then press enter.

b. After entering the web Prezi.com there are several menu options at the top. A log is a menu for entering your account after you register first. Get started is used to start creating Prezi when you don't have an account on Prezi. So click is get started.

c. After that, there are three choices here, basic, individual, and teams, there are free and paid options. If we want to use Prezi with a free license we choose basic and click basic again.

d. After that, fill in personal data by the column that has been provided to create an account Prezi.

The content of the learning media material produced in the study is related to the local wisdom of the Buminabung area. (Aswita, Putu, \& Suyanto, 2018) define local wisdom as intelligence produced by one's own experience and shared property. Own experience is an experience that someone feels in society and takes place continuously so that it becomes a culture. Furthermore, Rahyono explained that everyone 
has an identity that was built by culture, where it was inside there is wisdom. Wisdom is the identity of a community in the area. Local wisdom has a strategic position.

The local wisdom of the inserted Buminabung area is adjusted to the basic competencies of Social Arithmetic. Local wisdom-based learning media are teaching materials containing subject matter according to the curriculum that relates to the habits of the community in certain areas. The local wisdom-based media created is based on the wisdom of the Buminabung area so that in this case the local wisdom of Buminabung is included in the subject matter. This media is equipped with illustrations and contains activities commonly carried out around students so students better understand the material presented. The material in this media takes basic competencies in Social Arithmetic subjects in class VII.

The local wisdom of Buminabung included in the media includes the livelihoods of the Buminabung community, activities that are often carried out by people who are still related to the material published in the media, the hospitality of the Buminabung community, and others. Social arithmetic learning is expected to make students understand the concepts in trade, such as selling prices, purchase prices, profits, losses, and others. Local wisdom is inserted to make it easier for students to understand the material. Because if learning mathematics is done by utilizing the knowledge resources around them, then it will be much easier to understand the material presented. Because the application of knowledge found in schools can be seen real for the benefit of the environment around them.

\section{Conclusion}

Local wisdom-based learning media have been developed with the application of Prezi on social arithmetic material by collecting data on local wisdom on the livelihood of Buminabung residents by taking documentation in the form of photos and information related to the local wisdom put them on the slide Prezi. The development of local wisdom-based learning media with the application of Prezi on social arithmetic material is feasible to use in learning. Product feasibility is based on the assessment of material experts and media experts with an assessment of $80 \%$ in the feasible category and $91 \%$ in the very feasible category. The results of the trials carried out were small group trials in class VII A with a feasibility percentage of $76 \%$ in the feasible category. In the field trials conducted by class VII A MTs Ma'arif 05 Buminabung, the percentage was $79 \%$ in the feasible category. 


\section{References}

Al-Hammouri, S. (2018). The Effect of Using Prezi on Al Zaytoonah University Students' Performance in French Language Reading Skills. International Education Studies, 12(1), 128. https://doi.org/10.5539/ies.v12n1p128

Ali, A. J., Saher, A., \& Najwan, F. (2020). The Effect of Using Prezi Presentations in Science Teaching: Achievement and Attitudes. International Journal of Innovation, 14(5), 15.

Anderton, K. (2019). The Misconceptions About Math That Are Keeping Students From Succeeding. Forbes. https://www.forbes.com/sites/kevinanderton/2019/04/28/the-misconceptions-about-math-thatare-keeping-students-from-succeeding-infographic/

Anwar, M. S., Choirudin, C., Ningsih, E. F., Dewi, T., \& Maseleno, A. (2019). Developing an Interactive Mathematics Multimedia Learning Based on Ispring Presenter in Increasing Students' Interest in Learning Mathematics. Al-Jabar: Jurnal Pendidikan Matematika, 10(1), 135-150. https://doi.org/10.24042/ajpm.v10i1.4445

Apri Wahyudi \& Choirudin. (2019). Pengembangan Alat Peraga Pembelajaran Matematika Materi Perkalian Berbasis Montessori. Jurnal Manajemen Pendidikan Islam Al-Idarah, 4(2), 33-39.

Ariffin, A., Samsudin, M. A., Zain, A. N. Md., Hamzah, N., \& Ismail, M. E. (2017). Effects of Using Graphics and Animation Online Problem-Based Learning on Visualization Skills among Students. IOP Conference Series: Materials Science and Engineering, 203, 012022. https://doi.org/10.1088/1757899X/203/1/012022

Aruan, L., Sari, R., \& Bengar Harahap, A. (2020). Using Prezi Online Software to Improve Teaching Listening Skill. International Journal of Education and Literacy Studies, 8(1), 104. https://doi.org/10.7575/aiac.ijels.v.8n.1p.104

Aswita, D., Putu, S., \& Suyanto, S. (2018). Local wisdom of sabang island society (aceh, Indonesia) in building ecological intelligence to support sustainable tourism. GeoJournal of Tourism and Geosites, 22, 393. https://doi.org/10.30892/gtg.22210-297

Azhar Arsyad. (2014). Media Pembelajaran. PT RajaGrafindo Persada.

Baten, E., Pixner, S., \& Desoete, A. (2019). Motivational and Math Anxiety Perspective for Mathematical Learning and Learning Difficulties. In A. Fritz, V. G. Haase, \& P. Räsänen (Eds.), International Handbook of Mathematical Learning Difficulties (pp. 457-467). Springer International Publishing. https://doi.org/10.1007/978-3-319-97148-3_28

Byrne, L. B. (2016). Learner-Centered Teaching Activities for Environmental and Sustainability Studies. Springer.

Chamidy, T., Degeng, İ. N. S., \& Ulfa, S. (2020). The Effect of Problem Based Learning and Tacit Knowledge on Problem-Solving Skills of Students in Computer Network Practice Course. Journal for the Education of Gifted Young Scientists, 8(2), 691-700. https://doi.org/10.17478/jegys.650400

Choirudin, Eka Fitria Ningsih, M. Saidun Anwar, Intan Ratna Sari, \& Suci Amalia. (2020). Pengembangan Perangkat Pembelajaran Etnomatematika Pada Situs Purbakala Pugung Raharjo. Pi: Mathematics Education Journal, 3(1), 18-27. https://doi.org/10.21067/pmej.v3i1.3755 
Choirudin, Ningsih, E. F., Anwar, M. S., Choirunnisa, A., \& Maseleno, A. (2020). The Development of Mathematical Students Worksheet Based on Islamic Values Using Contextual Approach. International Journal on Emerging Mathematics Education, 3(2), 152-161. https://doi.org/10.12928/ijeme.v3i2.13286

Daniels, M. (1982). The development of the concept of self-actualization in the writings of Abraham Maslow. Current Psychological Reviews, 2(1), 61-75. https://doi.org/10.1007/BF02684455

Eriana, Kartono, \& Sugianto. (2019). Understanding Ability of Mathematical Concepts and Students' Selfreliance towards Learning by Implementing Manipulative Props (APM) on Jigsaw Technique. Journal of Primary Education, 8(2), 176-183.

Firdaus, L., Samsuri, T., \& Susantini, E. (2019). The Development Of Textbook Ecology Based On Local Wisdom To Improve Scientific Attitude Of Graduate Students. 8(12), 6.

Gall, M. D., Gall, J. P., \& Borg, W. R. (2014). Applying Educational Researcb: How to Read, Do, and Use Research to Solve Problems of Practice. Pearson Education.

Hartini, S., Misbah, M., Dewantara, D., Oktovian, R. A., \& Aisyah, N. (2017). Developing Learning Media Using Online Prezi into Materials about Optical Equipments. Jurnal Pendidikan IP A Indonesia, 6(2), 313. https://doi.org/10.15294/jpii.v6i2.10102

Haylock, D., \& Cockburn, A. D. (2017). Understanding Mathematics for Young Children: A Guide for Teachers of Children 3-7. SAGE.

Kamelia, K. (2019). Using Video as Media of Teaching in English Language Classroom: Expressing Congratulation and Hopes. Utamax: Journal of Ultimate Research and Trends in Education, 1(1), 34-38. https://doi.org/10.31849/utamax.v1i1.2742

Marini, A., Safitri, D., Nuraini, S., Rihatno, T., Satibi, O., \& Wahyudi, A. (2020). Applying Model Of Mobile Web-Based On Character Building In Teaching-Learning Process To Improve Student Character. International Journal of Advanced Science and Technology, 29(06), 1121-1124.

Nur Kumala, F., Agus Setiawan, D., Amin, M., Gipayana, M., \& Atul Karvilla, R. (2019). Problem-Based Prezi Multimedia: Elementary School Students' Thinking Skill. Universal Journal of Educational Research, 7(9), 1964-1969. https://doi.org/10.13189/ujer.2019.070916

Oemar Hamalik. (2014). Proses Belajar Mengajar. PT. Bumi Aksara.

Rusyfian, Z. (2016). Prezi Solusi Presentasi Masa Kini. Informatika.

Sari, A. P., \& Setiawan, A. (2018). The Development of Internet-Based Economic Learning Media using Moodle Approach. International Journal of Active Learning, 3(2), 1-10.

Setiawan, A., \& Wawan. (2020). Pengembangan E-Modul Pada Mata Kuliah Aljabar Prodi Matematika IAIM-NU Metro Lampung. Indonesian Journal of Instructional, 1(1), 54-61.

Subandi, Choirudin, Mahmudi, Nizaruddin, \& Hermanita. (2018). Building Interactive Communication with Google Classroom. International Journal of Engineering \& Technology, 7(2.13), 460-463.

Sugiyono. (2017). Metode Penelitian Kuantitatif, Kualitatif, dan R\&D. CV. Alfabeta.

Wati, M., Hartini, S., Novita, D., \& Mahtari, S. (2017). The Development of Teaching Media Based on PREZI Application at Fluid Dynamic Subject. Proceedings of the 5th SEA-DR (South East Asia Development Research) International Conference 2017 (SEADRIC 2017). 5th SEA-DR (South East Asia Development 
Development of Local Wisdom-Based Learning

Research) International Conference 2017 (SEADRIC 2017), Lambung, Indonesia. https://doi.org/10.2991/seadric-17.2017.3 